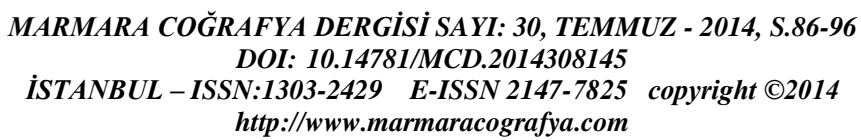

\title{
A BRIEF LOOK AT GENERAL AND ENVIRONMENTAL EDUCATION IN NIGERIA
}

\author{
Ahmad Said ABUBAKAR \\ Fatih Üniversitesi, Sosyal Bilimler Enstitüsü, Yüksek Lisans \\ ahmadsaidabubakr@yahoo.com
}

\begin{abstract}
The main aim of this study is investigating environmental education (EE) in Nigerian context. However, to provide the reader better understanding of EE, some fundamental information about the general education system in Nigeria was included. Keeping these aims in mind, the subjects covering schooling system, higher education, etc were given place within the study.

As for the EE in Nigeria, the issues covering the need for EE in Nigeria, the national and international forces affecting the EE in Nigeria, the place of EE in teaching programs, laws and Institutions concerning the environment, and EE in early ages etc.

At the end of the study, some recommendations were provided to contribute to improvement consciousness among Nigerian primary and secondary students and to development of the quality of general education system in Nigeria. In this section especially the effect of educational politics, planning in EE, parents' role, EE in non-formal education, and the importance of access to the sound information regarding EE were underlined.
\end{abstract}

Keywords: General education, environmental education, Nigeria, primary and secondary education.

\section{ÖZET}

Çalışmanın temel amacı, Nijerya'da çevre eğitiminin ele alınmasidır. Bununla birlikte konunun daha iyi anlaşılması amacıyla ve çevre eğitiminin genel eğitimin bir parçası olması nedeniyle Nijerya'da genel eğitim sistemi ile ilgili bilgiler de sunulmuştur. Bu amaca yönelik olarak çalışma sürecinde Nijerya'da okul sistemi, yüksek ögrretim gibi konulara da yer verilmiştir. 
Nijerya'da çevre ĕgitimi konusunda ise, Nijerya'da çevre eğitimine olan ihtiyaç, çevre eğitimini etkileyen ulusal ve uluslar arası faktörler, öğretim programlarında çevre eğitimi, çevre eğitimini ilgilendiren kanun ve kurumlar ve erken yaşlarda çevre eğitimi gibi konular ele alınmıştır.

Çalışmanın sonuç ve öneriler bölümünde ise Nijerya'da ilk ve ortaögretim öğrencilerinin çevre bilincinin geliştirilmesine katklda bulunmak ve yine Nijerya'da genel eğitimin problemlerinin çözümü adına bir takım öneriler getirilmiştir. Getirilen bu çözüm ve önerileri genel itibariyle ĕgitim politikaları, çevre eğitimi ile ilgili planlamalar, velilerin rolü, çevre eğitiminde yaygın eğitimin rolü ve çevre eğitimi ile ilgili doğru bilgilere ulaşılması gibi çeşitli meseleler üzerinde yoğunlaşmaktadır.

Anahtar kelimeler: Genel eğitim, çevre eğitimi, Nijerya, ilk ve ortaöğretim.

\section{INTRODUCTION}

Environment is considered as the most essential need for living things as it was defined as accommodation to either living or non-living being (Kneese, 1978:7; Umar, 2009:4; Whiston, 2000:1; Olofin, 2009:1 and Moriki, 2009:11). However, the role of education in raising environmental awareness is not overemphasis. Nowadays, many countries in the world have introduced the concept of EE in their educational curricula to include environmental courses and modify other science, social science and art courses such as Geography, Biology, Mathematics, History, Social Studies, etc.

Historically, the concept of "environmental education" had studied by different scholars using different terminologies such as: conservation education, nature study, environmental literacy, resourcebased education programs, outdoor education, place-based education, sustainability education, education for sustainable development, and other related names (Jacobson et al., 2006; Zint and Higgs, 2008).

Thus, environmental education does not have universal and acceptable definition, since there are various interpretations and definitions given by different experts or scholars. Despite this, some scholars defined it in a comprehensive manner. One of the most 
comprehensive definition of $\mathrm{EE}$ is given by Moseley (2000) as; a lifelong interdisciplinary approach which aimed at developing global people; through imposing conscious of environment and related issues to that people which contribute in solving existing environmental injustices and offer formation of new knowledge, skills, attitude, stimulus, personal and social duties and responsibilities (Moseley, 2000:23).

Similarly, the main objective of environmental education is focused on relationship and impact of humanity on environment. To have a systematic approach to EE; the following features must be achieved. These are: EE should be interdisciplinary in its approach, it must be comprehensive and holistic, and it should be long life process (Tuncer and Erol, 2007: 2; Hill, 1999:3-4 and Moseley, 2000:23).

\section{GENERAL EDUCATION SYSTEM IN NIGERIA}

\section{School System}

In Nigeria, the local, state, and federal governments are responsible for education. The 9-3-4 formulation is in use in current Nigerian education system. The basic education which comprises 9 years is consisted of 6 years primary school and another 3 years junior secondary school education which is compulsory and free of charge. After these 9 years of basic education, there is 3 years senior secondary school education which is not compulsory, although it is free of charge.

Early childhood education (crèche, nursery, and kindergarten) in Nigeria covers the ages between two and six. This non-compulsory education's main aim is to prepare pupils for primary education (Lawan, 2010).

On the other hand, children from 12 years and above enroll into secondary school education. The responsibility for secondary education rests on the shoulders of the state government. At the end of six years in the secondary school, the Senior Secondary Certificate Examination (SSCE), GCE, etc. are taken by the students in order to further their education, business or employment. Having five credits or more including English language will enable students to go to university after passing the UTME as well. Failure to have five credits disqualifies a student from pursuing a university degree; instead he can apply for a diploma, NCE, etc. Secondary education prepares individuals for useful 
sustainable living within society and also for higher education (Federal Republic of Nigeria, 1998: 17; Baikie, 2002).

At the SSS stage, students choose arts, science or vocational classes to complete their six years by spending three years in SSS. There are core and compulsory subjects. English language, mathematics, and one of the Nigerian languages are the compulsory subjects while others are selected based on students' interest. The aim is to prepare the students for both furthering their education and work. The subjects taught at this level are: accounting, agriculture, applied electricity, Arabic, auto mechanics, biology, chemistry, Christian religious studies, civic education, clothing and textiles, commerce, computer science and typing, English language, economics, food and nutrition, French, geography, government, history, home management, Islamic religious studies, literature in English, mathematics, mental work, music, Nigerian languages, physical education, physics, visual and woodwork (http://nigeria.usembassy.gov).

\section{Higher Education}

Although in 1963 there were only five universities across the country, this increased to 13 universities by 1977 and to 21 universities after five years (1982). Nowadays higher education pursues various institutes of learning such as universities, colleges of education, polytechnics, colleges of Islamic and legal studies, and other institutions offering different courses (Lawan, 2010). University education awards various bachelor degrees and lasts for four years, but some courses like medicine, agriculture, architecture, and engineering last longer than four years.

In addition, polytechnics offer two-year National Diploma and two-year Higher Diploma programs, while colleges of education offer three-year courses that lead to the award of the National Certificate of Education (NCE) (Ogueri, 2004). The goals of higher education are set out in the National Policy (Federal Republic of Nigeria, 1998) as:

- To provide manpower that helps in the development of the country

- To establish citizens who are self-sufficient and useful to the society 
- To build national unity and integration

- To develop and inculcate proper values for the survival of the individual and society.

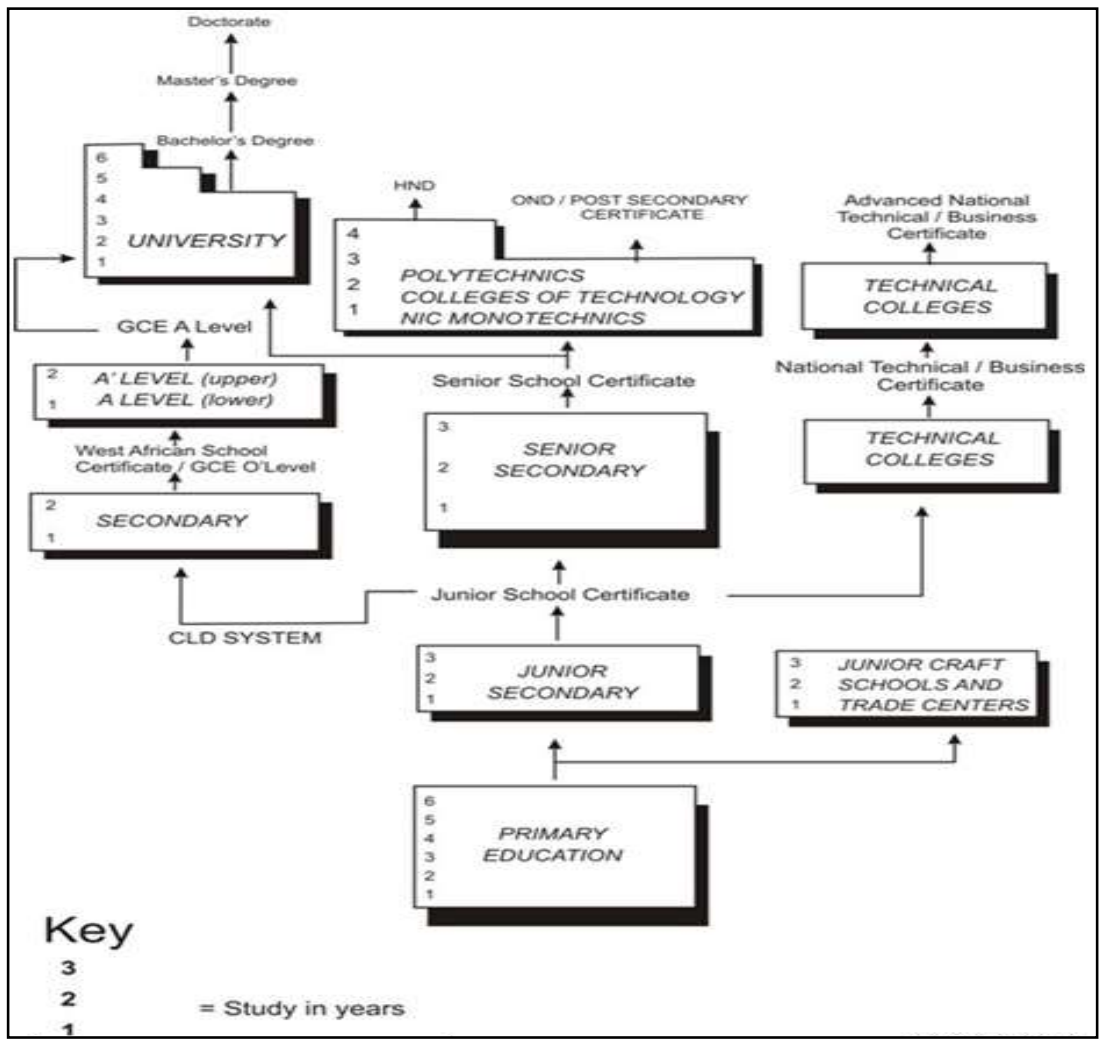

Figure 1: Education structure of Nigeria (FRN, 2011).

\section{EE IN NIGERIA}

The need for EE is essential and compulsory to education system in Nigeria. This need or demand for EE is as a result of discriminate and negative human activities on environment which cause environmental injustice, land degradation and pollution. This is because many Nigerians don't have knowledge, attitude, consciousness, value and awareness on environment (Olagunju, 1997 and Mansaray, Ajiboye, and Audu, 1998). For that, introducing EE as a course or subject into Nigerian education 
system is in needed. On the other hand, EE is not taught as a separate subject in Nigerian education system but rather is taught as multidisciplinary through existing subjects such as Social Studies, Geography, Integrated Science, Biology, Chemistry and Physics (Adekunle 2003: 73 and Robinson (2013: 4).

Although, Nigeria initiated EE program dated back to 1970s in order to response to the motion of the world summits on environmental issues. Equally, the Stockholm Conference of 1972, Belgrade Conference of 1975 as well as Tbilisi Conference of 1977, coupled with Earth Summit of Rio de Jenairo 1992 encourage Nigeria to wake up its citizens and awareness them on environmental problems facing Nigeria in particular and the world in general (Adekunle 2003: 73 and Oyewale 2007: 85).

Equally, the early1980s witnessed growth concern of environmental issues in Nigeria particularly at the non-formal level with setting up of the Nigeria Conservation Foundation (NCF).The Nigeria Educational Research Development Council (NERDC) and Nigerian Conservation Foundation (NCF) contributed immensely towards the development of $\mathrm{EE}$ among the formal and non-formal education in Nigeria (Aniemeka, 2009:3).

Similarly, Laws and Institutions concern on environment were promulgated and made by both military and democratic governments. Such Laws and Institution for example are:

- Water Ways Act (1915)

- Public Health Act (Amended 1958)

- Forest Ordinance (1937)

- Petroleum Drilling and production Regulation Act (1969)

- Navigable water Act (1968)

- Minerals Act (1969)

- Associated Gas reinjection Decree (1979)

- Federal Environmental protection Agency Act (1989)

- Natural Resource Conservation Council (1989)

- Land Use Decree (now Act 1978)

- Environmental Impact Assessment Act (EIA 1992)

- Federal Ministry of Environment Act (1999) and

- Oil Spill Detection and Response Agency (Robinson, 2013: 2). 
Many people conducted their research in Nigeria in general on EE, for example; Agnes and Nor (2011): examined the level of implementation of EE within the Malaysia and Nigeria. Conversely, Jekayinfa and Yusif and Ogueri (2004) and (2008) examined the students' teachers view on introduction of EE into secondary schools subject. In opposite side, Barau (n.d) made his research on an appraisal of the women's level of environmental education in Nigeria. Similarly, Agbogidi and Ofuoku (2007) carried out their research on promoting environmental protection through EE in Nigeria and the role of women. Equally, Muhammed conducted her research work on appraising the gender participation with particular emphasis on involvement of women in environmental management in Nigeria (Muhammed, 2012).

It is the best time to impart environmental consciousness to children at early age. This is because they do not have pressure on them and they can be influenced by childish habit. EE should be taught at early age because whatever child comprehends, it is hardly to fade away during that period up to the end of his life. As one wise man says, "comprehending at early age is just like writing on stone, while during adolescent is as to write on the water". EE program should start teaching participants at younger age. The pre-school and elementary years happen to be important stages in which environmental attitudes are formed (Peterson, 2005:299).

Children should be taught about environmental education before enroll into pre-nursery school. This is because, it is right stage to develop environmental attitude to them (Peterson 2005: 299).

Both formal and non-formal education is needed to impart environmental consciousness to the students at their younger age. This is because "learning starts from cradle to the grave" (Doka, 2006: 1). However, the main factors affecting the EE in Nigeria at all levels of education are lack of funding, insufficient management, lack of professionalism, and poor implementation of education policies.

\section{CONCLUSION AND RECOMMENDATIONS}

EE is of paramount importance to both developed and developing countries, but yet is a face a lot of challenges especially in developing 
world Nigeria is included. If the above recommendations are considered by both government and NGOS the problems will be minimized.

Practical projects such as making a garden, water treatment in the laboratory, etc should be carried out in both formal and non-formal education within the country.

Politics, short term planning on EE, duplication, etc are among the limitation of this research work. In order to have general idea of EE these aforementioned problems should be considered for future research.

Effectiveness of formal environmental engineering education has to be improved in university and equip them with teaching aids in order to help our future national human resources with knowledge of comprehensive environmental issues and enable the drawing up of legislation based on sound understanding of basic environmental principles. As the destiny of our country relies on high school students and undergraduate, this will help them enormously in decision making and policies making.

Similarly, non-formal education must pay attention upon in executing environmental education among public in Nigeria through enlightening and awareness campaign, publications of related materials by NGOs is not ignored. This helps students to understand the concept of "environment" painstakingly since before enrolling into grade 3 or 4 .

Equally, for the institutions, Ministry of Education; Ministry of Environment; Universities and experts should develop more structured and comprehensive plan that integrate economic, social and environmental aspect so as to be articulated in improving the contents of environmental aspect in the primary's, secondary's and university's syllabuses.

Also, parent should be educated about environmental challenges facing that society in particular and world in general through adult education or any mean as many parent (especially women) do not continue their education after finishing high school education in Nigeria.

Additionally, access to information regarding to environmental challenges as well as environmental literacy should be provided so as every individual will have access to it. 
Likewise, articles, books, journals, pamphlet, related degree project, master's thesis, doctoral dissertation and postdoctoral research, etc should be published so as every record would be storage for public use.

Thus, the main factor that increases the quality of and improves environmental literacy or education is teacher's knowledge, qualification, good perceiving of and level of consciousness about environment. For that, attention must pay on teachers' in-service on environmental related courses so as to have much knowledge about environment which they impart to their students.

Moreover, indoor and outdoor school activities should be emphasized on such planting trees, imagery show, poetry, sports, nature walking, etc for students to be motivated and gusto to work. As wise man says "education is nothing but action".

\section{REFERENCES}

Adekunle, M.O. (2003). Relationship between the Level of Education and Environmental Awareness of Secondary School Students in Oyo Metropolis. Journal of Oyo State College of Education Oyo, 11(1), 73-79.

Agbogidi, O. M. and Ofuoku, A. U. (2007). Promoting environmental protection in Nigeria through environmental education: the role of women. Journal of Environmental Extension, 6 (1), $17-24$.

Agnes, A. M. and Nor, A. M. (2011). Implementation of Environmental Education: A Case Study of Malaysian and Nigerian Secondary Schools. IPCBEE, 1(1), 326 - 327.

Aniemeka, E. O. (2013). Environmental Education, Training and Public Awareness in Nigeria: 18th APFEJ Congress of Environmental Journalists www.environmentaljournalists.org.

Barau A. S. (n.d). An appraisal of the women's level of environmental education in Kano, Nigeria. Department Of Geography Federal College Of Education, Kano, Nigeria. aliyubarau1@yahoo.co.uk +2348023893014 
Doka, A. S. (2006). Teaching qualification as its affect the teaching and learning of Geography in some selected schools in Bichi Zonal Education Area. Unpublished project of Post graduate diploma, Kano: Federal college of education.

Hill, R. (1999). Environmental education for a sustainable future national action plan. Australia: Commonwealth press.

Jacobson, S. K., McDuff, M. D. and Monroe, M. C. (2006), Conservation education and outreach techniques: New York: Oxford University Press.

Jekayinfa, A.A. and Yusuf, A.R. (2008). Teacher's opinions on the incorporation of environmental education in the Nigerian primary school curriculum. Education Research and Review, 3(11), 334-338.

Kneese, A.V. (1978). Environment and economics. Pp. 7.

Lawan, M. (2010). Current foundation and development in Nigeria: Mohadiz Global Link Press, Kano. Pp. 2-102.

Mansaray, A., Ajiboye, J. O. and Audu, U. F. (1998). Environmental knowledge and attitude of some Nigerian secondary school teachers. Environmental Education Research, 4(3) and National Commission for Colleges of Education. Newsletter, 1996, 4 (1), 329-339.

Mohammed, N. (2012). Gender participation in environmental management in Tofa local government area of Kano state. Implications for Sustainable Development. British Journal of Arts and Social Sciences, 9 (II), 156-167.

Moriki, N. I. (2009). To know your environment, is to know yourself. Dala Geographer Journal, 10 (1), 1-52.

Moseley, C. (2000). Teaching for environmental literacy. Clearing House, 74(1), 23-25.

Ogueri, A. C. (2004). The Need for environmental education in secondary education level in Nigeria: Problems and Challenges. International masters degree thesis on environmental policy department of environment, technology and social studies, Roskilde University: Denmark. Pp. 68-9 
Olagunju, A.M. (1998). Environmental education in senior secondary school biology curriculum for improved performance, problem solving and environmental attitude. Unpublished $\mathrm{Ph} . \mathrm{D}$. thesis, Department of teacher education, university of Ibadan: Ibadan.

Olofin, E. A. (2011). Lecture note on environment and development, Kano: Geography department Bayero University, Kano. Pp. 1

Oyewale, A.O. (2007). Secondary school teachers' knowledge of environmental education concept in selected local government area of Oyo State in Nigerian. Journal of Social Studies, 1 and 2(1), 85-93.

Peterson, N. (2005). Factors influencing the development of environmental sensitivity: A Model. In essential readings in environmental education, (pp 295-299). Champaign: Stipes Published L.L.C. Potter, G. (2010). Environmental education for the 21st century: Where do we go now? The Journal of Environmental Education, 4(1), 22-33.

Robinson, J. O. (2013). Environmental education and sustainable development in Nigeria: Breaking the Missing Link. International Journal of Education and Research, 1 (5), 1-6.

Tuncer, M. and Erol, D. (2007). The environmental education in turkey: some views and proposals of biopolitics. http://www.biopolitics.gr/BIOPOLITICS/HTML/PUBS/VOL 4/fe-tunce.htm

Umar, N. (2009). To know your environment, is to know yourself. Dala Geographer Journal, 10 (1), 1-52.

Whiston, T.G. (2000). Environmental consciousness and the challenges and barriers to communicating environmental knowledge indicators: In quality of life, Sustainability and Environmental Challenges: Austrian research centers. Pp. 1.

Zint, M. and Higgs, A. (2008). A brief history of environmental education: Society for Conservation Biology www.conbio.org/WorkingGroups/SSWG/catalog/education.c fm. 